\title{
Effect of Nitrogen Fertilizer Types and Microelements on Growth, Yield and Chemical Constituents of Tuberous Root of Sweet Potato (Ipomoean batatas L, Lam)
}

\author{
Ali, R.A.M \\ Vegetable, Department, Agriculture Research center, El-Dokki, Egypt
}

\begin{abstract}
In this study, the effect of nitrogen fertilizer types, micronutrients mixture concentrations foliar application and their interactions on growth, yield of tuberous root and chemical characteristics of sweet potato were investigated. The treatments included four nitrogen fertilizer types; $60 \mathrm{~kg} \mathrm{fed}^{-1}$ (full recommended dose of mineral $\mathrm{N}$ fertilizer) $; 15 \mathrm{~kg} \mathrm{fed}^{-1}$ mineral $\mathrm{N}$ fertilizer $(1 / 4$ recommended dose $)+1.5 \mathrm{~m}^{3}$ compost fed. ${ }^{-1} ; 30 \mathrm{~kg} \mathrm{~N}$ fed. ${ }^{-1}$ mineral N fertilizer $(1 / 2$ recommended dose $)+1 \mathrm{~m}^{3}$ compost fed. ${ }^{-1}$ and $45 \mathrm{~kg} \mathrm{fed}^{-1}$ mineral $\mathrm{N}$ fertilizer $(3 / 4$ recommended dose $)+0.5 \mathrm{~m}^{3}$ compost

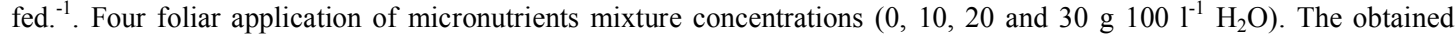
result indicated that application of full recommended dose of mineral $\mathrm{N}$ fertilizer significantly increased plant length, number of branches, vine fresh weight, root length, root diameter, number of root plant ${ }^{-1}$ and total yield characters. However $15 \mathrm{~kg}$ fed. ${ }^{-1}$ mineral $\mathrm{N}$ fertilizer $(1 / 4$ recommended dose $)+1.5 \mathrm{~m}^{3}$ compost fed. $^{-1}$ or $30 \mathrm{~kg} \mathrm{fed}^{-1}$ mineral N fertilizer $(1 / 2$ recommended dose $)+1 \mathrm{~m}^{3}$ compost fed. ${ }^{-1}$ gave the highest mean values of total sugars, starch, root dry matter and carotene. Moreover, micronutrient at $30 \mathrm{~g} 100 \mathrm{l}^{-1}$ increased significantly all the vegetable and yield characters. The best results on vegetative growth, yield and chemical constituents were achieved when sweet potato plants fertilized

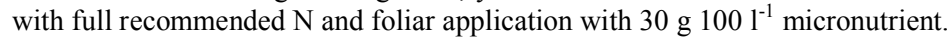

Key words: Nitrogen Fertilizers- micro elements- compost- sweet potato.

\section{INTRODUCTION}

Sweet potato (Ipomoea batatas L, Lam) is considered as one of food resource and plays a great role in solving the problem of food especially as one of the most in the developing countries. Sweet potato has a high edible biomass index because foliage and storage roots can be consumed. Sweet potato can be used as a sweet dessert in preparing a variety of convenience processed products such as a fast and snack food, a multipurpose flour, an alcoholic or nonalcoholic drinks, and starch (Abd El-Aal et al. 2010).

Sweet potato is high in carbohydrates carotene, vitamins (B1, B2, C) and elements $(\mathrm{Na}, \mathrm{P}, \mathrm{K}, \mathrm{Ca}$, $\mathrm{Mg}$ ). It yields two useful food types from the same plant, namely, fleshy storage roots and green tops (vines consisting from stems and leaves), which can be used as nutrition food for human and animal feeding, respectively.

Sweet potato is a very sensitive plant to nutritional balance super optimal of nitrogen application repressed partitioning of nitrogen assimilates to roots promoting growth of new shoots and consequently had negative effects on yield and quality of sweet potato (Njira and Nabwami, 2015). Nutrition either by mineral nitrogen and / or organic nitrogen fertilizers is considered the most important agriculture practice which affect the duration of growing period of plant foliage, tuberous root formation and quality of sweet potato.

Adding compost to soil enriched it with elements to maintain soil fertility, improves and maintains crop production (Khairi et al. 2016). It is well know that organic matter improved the structure of the soil and this consequently encourage the plant to have a good growth. Moreover, the slow released nutrients contained in organic matter permit the plants to beneficial of it (Nwite, 2016). The biological activity, and biodiversity, can also be improved through organic fertilizer (Agyarko, 2014). The soils are poor in organic matter and available nutrients; and hence productivity and sustainability decline over time.

Foliar spraying of microelements is very helpful when the roots cannot provide necessary nutrients (Babaeian et al. 2011). Moreover, soil application of micronutrients increases soil pollution. As people are concerned about the environment and plant leaves absorb nutrients better than soil application, foliar spraying was created (Bozorgi et al. 2011). Crop roots are unable to absorb some important nutrients such as zinc, because of soil properties, such as high $\mathrm{pH}$ and lime, thus, in this situation, foliar spraying is better as compared to soil application (Kinaci and Gulmezoglu, 2007). Foliar application of microelements improves the effectiveness of macronutrients (Narimani et al. 2010). The application of micronutrient foliar fertilizer has positive effect in sweet potato. Foliar application of microelement is reported to improve growth, yield and quality (El-Tohamy et al. 2014). Also, reported to improve yield of many crops which the underground part is economically important (Mousavi et al. 2007; Panitnok, et al. 2013; Hafeez et al. 2013 and Rani, 2015). 
It is well known that high yielding with good quality are essential for the production of a satisfactory crop of vegetables for both growers and consumers. So, there are some factors influencing the productivity of sweet potato, which include soil management practice, fertilizer application

Therefore, the main objectives of this investigation were to study the effects of different mineral and organic fertilizer treatments as well as foliar application of micronutrients and their interactions on vegetative growth, yield, quality and chemical components of sweet potato plants.

\section{MATERIALS AND METHODS}

The present study was conducted at the Experimental Farm of South Tahrir Horticulture Research Station, at the Ali Moubarak village, ElBostan region, Behera, Egypt during the two successive summer seasons of 2017 and 2018, to study the effect of fertilizer types and foliar application of micronutrient mixture on the growth, tuberous root yield and quality of sweet potato. Prior to the initiation of the investigation, in each season, soil samples from the soil surface of the two experimental sites up to $40 \mathrm{~cm}$ depths were collected and analyzed for some chemical and physical properties according to the standard procedures of (page, 1982). Results of analysis are presented in Table 1.

Uniform stem cuttings, $25 \mathrm{~cm}$ length of sweet potato cv. Abies were manually transplanted on the first April, in two growing seasons at in row spacing of $25 \mathrm{~cm}$. Stem cuttings were treated with dilute fungicide solution for 25 minute brior transplanting. Cutting were transplanted on the side of GR drip irrigation lines at ridges 1 meter width and $30 \mathrm{~cm}$ apart from each other.

\section{Treatments}

Four different types of nitrogen fertilizer; organic and chemical $\mathrm{N}$ fertilizers, with total $60 \mathrm{~kg}$ $\mathrm{N}$ fed., were tested as follow:

1- $60 \mathrm{~kg} \mathrm{fed}$ - $^{-1}$ (full recommended dose of mineral $\mathrm{N}$ fertilizer).

2- $15 \mathrm{~kg}$ fed. $^{-1}$ mineral $\mathrm{N}$ fertilizer $(1 / 4$ recommended dose) $+1.5 \mathrm{~m}^{3}$ compost fad. ${ }^{-1}$

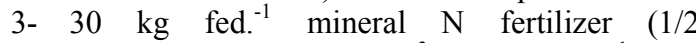
recommended dose $)+1 \mathrm{~m}^{3}$ compost fed. ${ }^{-1}$

4- $45 \mathrm{~kg}$ fed. $^{-1}$ mineral $\mathrm{N}$ fertilizer $(3 / 4$ recommended dose) $+0.5 \mathrm{~m}^{3}$ compost fed.

Ammonium nitrate $(33.5 \% \mathrm{~N})$ was used as the source of inorganic $\mathrm{N}$ fertilizer and added with irrigation water using venture injector. The drip irrigation system was consisted of laterals GR of, 16 $\mathrm{mm}$ in diameter with drippers had a discharge rate of, $4 \mathrm{Lh}^{-1}$.

The levels of compost of each the studied types of $\mathrm{N}$ fertilizer was added during the preparation of the experimental sites. The used compost was obtained from El-Slam compost Co.

While, the foliar application of micronutrient mixtures with four concentrations $(0,10,20$ and $30 \%$ ). The mixture of micronutrients ( $\mathrm{Fe}, \mathrm{Zn}, \mathrm{Mn}$ and $\mathrm{Cu})$ added as Fe-EDTA $(6 \% \mathrm{Fe}), \mathrm{Zn}$-EDTA $(15 \% \mathrm{Zn})$, Mn-EDTA $(12 \% \mathrm{Mn})$ and $\mathrm{CuSO}_{4} .5 \mathrm{H}_{2} \mathrm{O}$ $(25.45 \% \mathrm{Cu})$ with four different concentrations $(0$,

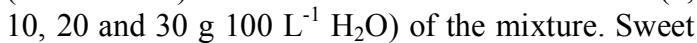
potato plants were sprayed with micronutrients solution during the two growing seasons, at 15, 30, 45, 60 and 75 DAT at rate $200 \mathrm{~L}^{-1} \mathrm{H}_{2} \mathrm{O} \mathrm{\textrm {fad } ^ { - 1 }}$ (Sanginga, 2015).

Table 1: Some physical and chemical properties of the experimental sites of the two growing summer seasons of 2017 and 2018.

\begin{tabular}{|c|c|c|}
\hline \multirow{2}{*}{ Properties } & \multicolumn{2}{|c|}{ Growing Seasons } \\
\hline & 2017 & 2018 \\
\hline $\mathrm{PH}$ & 8.1 & 8.0 \\
\hline Sand (\%) & 94.0 & 93.7 \\
\hline Silt (\%) & 0.05 & 0.06 \\
\hline Clay $(\%)$ & 5.5 & 5.46 \\
\hline Soil texture class & Sandy & Sandy \\
\hline $\mathrm{CaCO}_{3}(\%)$ & 1.43 & 1.51 \\
\hline Total N (\%) & 0.007 & 0.008 \\
\hline \multicolumn{3}{|c|}{ Available Nutrient (ppm) } \\
\hline $\mathrm{P}$ & 0.33 & 0.30 \\
\hline $\mathrm{K}$ & 0.20 & 0.22 \\
\hline
\end{tabular}

Table 2: Properties of the used compost during the two growing seasons .

\begin{tabular}{|c|c|c|c|c|c|c|}
\hline $\begin{array}{l}\text { Moisture } \\
(\%)\end{array}$ & 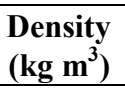 & $\begin{array}{c}\text { Organic matter } \\
(\%)\end{array}$ & pH & $\begin{array}{l}\mathrm{N} \\
(\%)\end{array}$ & $\begin{array}{c}\mathbf{P} \\
(\%)\end{array}$ & $\begin{array}{l}\mathrm{K} \\
(\%) \\
\end{array}$ \\
\hline 10.5 & 350 & 25.8 & 7.5 & 0.9 & 0.8 & 1 \\
\hline
\end{tabular}


All experimental unites received identical levels of phosphorus and potassium fertilizers and fertigated at rates of 80 and $100 \mathrm{~kg}$ of $\mathrm{P}_{2} \mathrm{O}_{5}$ and $\mathrm{K}_{2} \mathrm{O}$ fed. $^{-1}$, respectively as phosphoric acid (58\%) and potassium sulphate ( $48 \%$ ).

All agricultural practices such as cultivation, disease and pest control were carried out when it was necessary according to the commercial production of sweet potato.

\section{Experimental design}

The used experimental layout was arranged as a split-plot in a randomized complete blocks design (R.C.B.D), with three replicates. Four treatments of fertilizer types $\left(120 \mathrm{~kg} \mathrm{fed}^{-1}\right.$; $60 \mathrm{~kg}$ fed. ${ }^{-1}$ mineral $\mathrm{N}$ fertilizer; $60 \mathrm{~kg}$ fed. $^{-1}$ mineral $\mathrm{N}$ fertilizer and $90 \mathrm{~kg}$ $\mathrm{fed}^{-1}$ mineral $\mathrm{N}$ fertilizer) as a main plots, and four sub-plot of micronutrient mixtures with four concentrations $(0,10,20$ and $30 \%)$ were randomly distributed in the sub plots in the three replicates. Each plot consisted of 4 ridges and total area of subplot $7 \mathrm{~m}^{2}$.

\section{Data recorded}

Vegetative growth characters: plant length, number of leaves plant ${ }^{-1}$ and number of main branches plant $^{-1}$ were determined after 120 days from planting.

Yield and its components of tuberous roots: such as number of tuber roots plant ${ }^{-1}$, total tuber yield ton fad. $^{-1}$ were determined. In addition, sweet potato tuberous root characters such as average root weight $(\mathrm{g})$, root length $(\mathrm{cm})$, root diameter $(\mathrm{cm})$.
The harvested tuber roots were cured by drying. Random samples of tuber roots from each experimental unit were dried in oven at $70^{\circ} \mathrm{C}$ until to constant weight and then dry matter (\%) was determined.

Chemical constituents of sweet potato tuberous roots: dry matter of tuber (\%); total sugar; (mg.g ${ }^{1}$.d.w) of each sample was determined according to Malik and Singh, 1980, \% starch and total carotene content methods (A.O.A.C, 1990).

\section{Statistical analysis}

All the data recorded throughout the study were, statistically analyzed according to the design used by the CoStat software package for Windows (2004). The revised least significant differences among the means of the various treatment combination (Snedecor and Cochran, 1980).

\section{RESULTS AND DISSECTION}

\section{Vegetative growth characters}

The results of the two seasons (fig.1) indicated, generally, that fertilization of sweet potato plants with $60 \mathrm{~kg} \mathrm{~N}$ fed. ${ }^{-1} ; 35 \mathrm{~kg} \mathrm{~N}$ fed. ${ }^{-1}+1 \mathrm{~m}^{3}$ compost or $45 \mathrm{~kg} \mathrm{~N}$ fed. ${ }^{-1}+1.5 \mathrm{~m}^{3}$ fed. $^{-1}$ compost fed. ${ }^{-1}$ produced plants with the highest fresh weight of the above ground plants. Whereas the lowest mean value was recorded when plants received $15 \mathrm{~kg} \mathrm{~N}$ fed. $^{-1}+1.5 \mathrm{~m}^{3}$ compost fed..$^{-1}$. The results, also, indicated that increasing the level of minerals $\mathrm{N}$ up to $60 \mathrm{~kg} \mathrm{~N}$ fed. ${ }^{-1}$ and lowering the rate of compost to $0.5 \mathrm{~m}^{3}$ fed. $^{-1}$ progressively and significantly increased plants length and number of branches plant $^{-1}$.

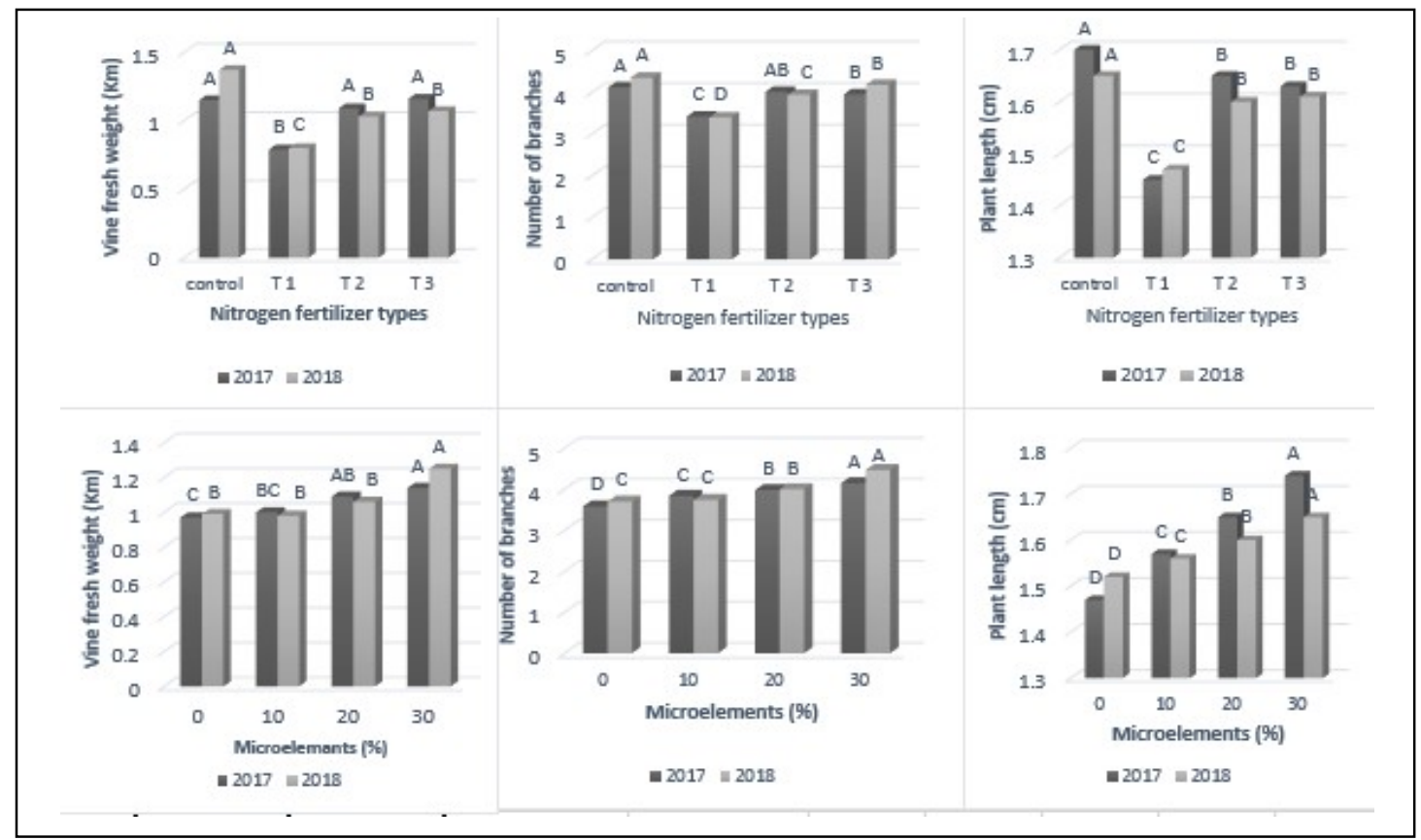

Fig. 1: Effect of Nitrogen fertilizer types and microelements concentrations on vegetative growth characters of sweet potato during both seasons of 2017 and 2018. 
The improving effect of $\mathrm{N}$ fertilizer types on vegetative growth characters could be mainly related to the high nutritive requirements of sweet potato plants as well as increasing the uptake of minerals fertilizers which reflected on improving the physical $\backslash$, chemical and biological properties through the use of compost.

The stimulation effect of applying $\mathrm{N}$ on vegetative growth characters of sweet potato may be attributed to role of $\mathrm{N}$ in plants life. Nitrogen is known as an essential element for proteins nucleic acids and chlorophyll formation pigments. Moreover, it stimulants the merstimic activity which in two results in more new tissues and organs (Kolodzeiejczyk, 2014).

The favorable effects of applied compost on vegetative growth characters can be explained on the basis that the sandy soils of the experimental sites had relatively low amounts of nutrients, thus the application of compost at 1.0 to $1.5 \mathrm{~m}^{3} \mathrm{fed}^{-1}$ improved the physical, chemical and biological properties of the soil during the growing period which was reflected on sweet potato tuberous root. Meissner-Smejkal, (2000) reported that the incorporation of organic manures in sandy soils can increase nutrients availability, cation exchange capacity and organic manure content, which in turn, stimulates plant growth and productivity. Recent studies indicated that composted manure has the potential to faster the biological process in soil and help in the creation and preservation of soil fertility. The present results are in accordance with those reported by Ashoure and Sarhan (1998) who indicated that the application of different organic manure combined with inorganic fertilizers gave the highest foliage fresh weight plant $^{-1}$ and plant lenght compared with control (mineral fertilizer only). The treatment received $25 \%$ city garbage with $75 \%$ inorganic fertilizer gave the highest significant increase in both foliage fresh weight and plant height than the control of treatment.

The results revealed, also, that increasing the concentration of foliar applied microelements mixture up to $30 \mathrm{gm} 100 \mathrm{l}^{-1}$ constantly and significantly increased fresh weight of vines and number of branches plant ${ }^{-1}$ as well as plant length comparing with untreated control plants.

The favorable effect of micronutrients on plant growth might be due to its role in many physiological processes and cellular functions within plants. In addition, they also play an important role in improving plant growth through biosynthesis of endogenous hormones, which are responsible for promoting of plant growth (Khairi et al., 2016 Rani, 2015 and Ali and Abd-Elkader, 2014).

The interaction effect between nitrogen fertilizer types and microelements, levels was illustrated in Table (3). The interaction effect was significant on plant length, number of branches and vine fresh weight in both seasons. The combined treatment at $30 \%$ recorded the highest mean values for the vegetative growth characters.

\section{Tuberous root yield and its components}

Data arranged in Fig. (2) and Table (4) illustrated the main effects of the two studied factors as well as their interaction on the tuberous root yield and its components. The results of the maine effect of nitrogen fertilizer types reveled significant and progressive increases in the total tuberous yield and average fresh weight of tuberous root as a results of increasing $\mathrm{N}$ up to $60 \mathrm{~kg} \mathrm{~N}$ fed. ${ }^{-1}$. So, the highest means values were recorded with the application of $60 \mathrm{~kg} \mathrm{~N}$ fed. $^{-1}$ or $30 \mathrm{~kg} \mathrm{~N}$ fed. ${ }^{-1}+1 \mathrm{~m}^{3}$ compost fed. 1. On the other hand, application $15 \mathrm{~kg} \mathrm{~N}+1.5 \mathrm{~m}^{3}$ compost produced the smallest mean values of total yield and fresh weight. Respecting tuberous roots by count, the results showed that the plants which received $30 \mathrm{~kg} \mathrm{~N}+1 \mathrm{~m}^{3}$ compost fed. ${ }^{-1}$ produced the highest number of roots followed by fertilization with $60 \mathrm{~kg} \mathrm{~N}$ fed. $^{-1}$, while, the lowest mean value was obtained with the application of $15 \mathrm{~kg} \mathrm{~N}+1.5$ $\mathrm{m}^{3}$ fed. ${ }^{-1}$. Regarding the response of root length and diameter, the results showed that the longest and thickness tuberous roots were recorded with the application of $60 \mathrm{~kg} \mathrm{~N}$ fed. ${ }^{-1}$ or $30 \mathrm{~kg} \mathrm{~N} \mathrm{fed} .^{-1}+1 \mathrm{~m}^{3}$ compost fed. ${ }^{-1}$.

The detective positively effects of mineral $\mathrm{N}$ on the total tuberous root yield might be related to its promoting effects on vegetative growth characters which probably supplied more photosynthesis products and hence, might help in increasing yield potential.

These results might be due to the insufficient quantity and perhaps the efficient absorption of $\mathrm{N}$ coupled together may promote the production of more photosynthetic required for tuberous root formation. These results seemed to be in accordance with those reported by Feleafel (2001) who found that application of $45 \mathrm{~kg} \mathrm{~N}$ fed. ${ }^{-1}$ to the growing plants of sweet potato reflected positive influences on marketable and total tuberous root yield. Similarly, results were also reported by Raghav and Kamal (2009); Zaman (2011); Nedunchezhiyan et al., (2010); Panwar and Wani (2014) and Sowley et al., (2015).

The increased yield plant ${ }^{-1}$ might be due to the previously noticed increased on vegetative growth and number and weight of tuberous roots. The increased tuberous roots diameter, resulted from the addition of nitrogen fertilizer could be attributed to increases on number of cells and / or cell size, as reported by feleafel (2001) who illustrated that sweet potato plants fertilized with nitrogen at rate of $45 \mathrm{~kg} \mathrm{~N}$ fed..$^{-1}$ produced significantly the highest mean values of total yield plant $^{-1}$ and its components. 
Table 3:- Effect of the interaction between $N$ fertilizer types and concentrations of microelements mixtures on vegetative growth characters of sweet potato during the summer seasons of 2017 and 2018.

\begin{tabular}{|c|c|c|c|c|}
\hline Treatments & & $\begin{array}{l}\text { Plant length } \\
(\mathrm{cm})\end{array}$ & No. of branches & $\begin{array}{c}\text { Vine fresh weight } \\
(\mathrm{Kg})\end{array}$ \\
\hline $\mathrm{N}$ fertilizer types & $\begin{array}{c}\text { Micro elements } \\
(\%)\end{array}$ & \multicolumn{3}{|c|}{ Summer Season 2017} \\
\hline \multirow{4}{*}{ Control } & $\cdot$ & $1.50 \mathrm{~g}$ & $3.69 \mathrm{e}$ & $1.00 \mathrm{c}-\mathrm{f}$ \\
\hline & 10 & $1.67 \mathrm{~d}$ & $4.06 \mathrm{~b}-\mathrm{d}$ & $1.10 \mathrm{a}-\mathrm{e}$ \\
\hline & 20 & $1.76 \mathrm{~b}$ & $4.36 \mathrm{a}$ & $1.20 \mathrm{a}-\mathrm{c}$ \\
\hline & 30 & $1.88 \mathrm{a}$ & $4.4 \mathrm{a}$ & $1.31 \mathrm{a}$ \\
\hline \multirow{4}{*}{$\mathrm{T} 1$} & $\cdot$ & $1.31 \mathrm{i}$ & $3.33 \mathrm{f}$ & $0.73 \mathrm{~g}$ \\
\hline & 10 & $1.41 \mathrm{~h}$ & $3.33 \mathrm{f}$ & $0.72 \mathrm{~g}$ \\
\hline & 20 & $1.49 \mathrm{~g}$ & $3.36 \mathrm{f}$ & $0.84 \mathrm{fg}$ \\
\hline & 30 & $1.60 \mathrm{ef}$ & $3.7 \mathrm{e}$ & $0.88 \mathrm{e}-\mathrm{g}$ \\
\hline \multirow{4}{*}{ Т 2} & $\cdot$ & $1.57 \mathrm{f}$ & $3.66 \mathrm{e}$ & $0.97 \mathrm{~d}-\mathrm{f}$ \\
\hline & 10 & $1.59 \mathrm{f}$ & $3.96 \mathrm{~d}$ & $1.15 \mathrm{a}-\mathrm{d}$ \\
\hline & 20 & $1.68 \mathrm{~d}$ & $4.13 \mathrm{bc}$ & $1.10 \mathrm{a}-\mathrm{e}$ \\
\hline & 30 & $1.75 \mathrm{bc}$ & $4.33 \mathrm{a}$ & $1.16 \mathrm{a}-\mathrm{d}$ \\
\hline \multirow{4}{*}{ Т 3} & $\cdot$ & $1.50 \mathrm{~g}$ & $3.63 \mathrm{e}$ & $1.16 \mathrm{a}-\mathrm{d}$ \\
\hline & 10 & $1.62 \mathrm{e}$ & $4.00 \mathrm{~cd}$ & $1.03 \mathrm{~b}-\mathrm{f}$ \\
\hline & 20 & $1.69 \mathrm{~d}$ & $4.06 \mathrm{~b}-\mathrm{d}$ & $1.23 \mathrm{ab}$ \\
\hline & 30 & $1.73 \mathrm{c}$ & $4.16 \mathrm{~b}$ & $1.21 \mathrm{a}-\mathrm{c}$ \\
\hline & & \multicolumn{3}{|c|}{ Summer Season 2018} \\
\hline \multirow{4}{*}{ Control } & $\cdot$ & $1.57 \mathrm{e}-\mathrm{g}$ & $3.86 \mathrm{e}-\mathrm{h}$ & $1.46 \mathrm{ab}$ \\
\hline & 10 & $1.61 \mathrm{de}$ & $4.16 \mathrm{c}-\mathrm{e}$ & $1.22 \mathrm{~cd}$ \\
\hline & 20 & $1.68 \mathrm{bc}$ & $4.43 \mathrm{bc}$ & $1.28 \mathrm{~b}-\mathrm{d}$ \\
\hline & 30 & $1.75 \mathrm{a}$ & $5.00 \mathrm{a}$ & $1.51 \mathrm{a}$ \\
\hline \multirow{4}{*}{$\mathrm{T} 1$} & $\cdot$ & $1.42 \mathrm{j}$ & $3.16 \mathrm{i}$ & $0.70 \mathrm{j}$ \\
\hline & 10 & $1.48 \mathrm{i}$ & $3.12 \mathrm{i}$ & $0.76 \mathrm{ij}$ \\
\hline & 20 & $1.48 \mathrm{i}$ & $3.15 \mathrm{hi}$ & $0.85 \mathrm{~g}-\mathrm{j}$ \\
\hline & 30 & $1.50 \mathrm{hi}$ & $3.18 \mathrm{e}-\mathrm{h}$ & 0.90 ghi \\
\hline \multirow{4}{*}{$\mathrm{T} 2$} & $\cdot$ & $1.54 \mathrm{gh}$ & $3.76 \mathrm{f}-\mathrm{h}$ & $0.80 \mathrm{~h}-\mathrm{j}$ \\
\hline & 10 & $1.56 \mathrm{fg}$ & $3.73 \mathrm{gh}$ & $0.93 \mathrm{f}-\mathrm{i}$ \\
\hline & 20 & $1.61 \mathrm{de}$ & $3.96 \mathrm{e}-\mathrm{g}$ & $1.00 \mathrm{e}-\mathrm{g}$ \\
\hline & 30 & $1.70 \quad \mathrm{~b}$ & $4.36 \mathrm{~b}-\mathrm{d}$ & $1.41 \mathrm{a}-\mathrm{c}$ \\
\hline \multirow{4}{*}{ Т 3} & $\cdot$ & $1.55 \mathrm{gh}$ & $4.03 \mathrm{~d}-\mathrm{g}$ & $0.98 \mathrm{f}-\mathrm{h}$ \\
\hline & 10 & $1.60 \mathrm{f}-\mathrm{e}$ & $3.86 \mathrm{e}-\mathrm{h}$ & $1.03 \mathrm{e}-\mathrm{g}$ \\
\hline & 20 & $1.64 \mathrm{~cd}$ & $4.13 \mathrm{c}-\mathrm{f}$ & $1.11 \mathrm{~d}-\mathrm{f}$ \\
\hline & 30 & $1.65 \mathrm{~cd}$ & $4.73 \mathrm{ab}$ & $1.18 \mathrm{de}$ \\
\hline
\end{tabular}

Control: $60 \mathrm{Kg}$ N\fed. $\mathrm{T} 1 .: 15 \mathrm{Kg} \mathrm{N} / \mathrm{fed}+1.5 \mathrm{~m}^{3}$ compost
$\mathrm{T} 2: 30 \mathrm{Kg} \mathrm{N} / \mathrm{fed}+1 \mathrm{~m}^{3}$ compost

T 3.: $45 \mathrm{Kg} \mathrm{N} /$ fed $+0.5 \mathrm{~m}^{3}$ compost

*Values followed by the same alphabetical letter(s) in common, within a particular group of means in each character, do not significantly differ, using Revised L.S.D test at 0.05 level of probability.

Concerning the main effects of micro elementals mixture on the tuberous root and its components, the results of the two seasons clearly reveled that increasing the level of foliar application of microelements mixture in the foliar spray solution up to $30 \mathrm{~g} 1001^{-1}$ constantly significantly increased total yield of tuberous and its components.

The stimulating effects of the micronutrients mixtures on sweet potato plants can be explained based on that micronutrient such as $\mathrm{Mn}, \mathrm{Zn}, \mathrm{Cu}$ and
Fe are essential for crop yield and they play an important role in balance crop nutrition (Ali and Abd-Elkader, 2014).

The results reflecting the effects of the interactions between the two studied factors, in the two seasons, on the tuberous root yield and its components are shown in Table (4). The components among the mean values of the combination treatments of each characters indicated that application of $60 \mathrm{~kg} \mathrm{~N}$ fed. ${ }^{-1}$ without compost 
combined with the highest concentration of

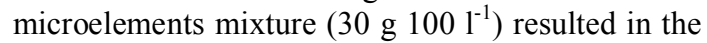
highest significant increases on the total yield, number of tuberous root plant $^{-1}$, fresh weight of tuberous root as well as length and diameter of root. However, the differences between $60 \mathrm{~kg} \mathrm{~N}$ fed. $^{-1}$ without compost and $30 \mathrm{~kg} \mathrm{~N}$ fed. ${ }^{-1}+1 \mathrm{~m}^{3}$ compost fed. $^{-1}$ were the same in average number of roots plant and total yield fed. ${ }^{-1}$ in both seasons and in root length and root diameter in the first season only. Whereas, the lowest mean values of the tested characters were recorded with the plants fertilized with $15 \mathrm{~kg} \mathrm{~N}$ fed. ${ }^{-1}+1.5 \mathrm{~m}^{-3}$ compost fed. ${ }^{-1}$ together with 0.0 or $10 \mathrm{~g}$ microelements mixture $100 \mathrm{l}^{-1}$. Such an increase on the tuberous root yield and its components could be related to the enhancing effects of each involved factors on the developments of vegetative growth, which consequently increased the productivity of tuberous roots plant ${ }^{-1}$, either by weight or count, and finally total tuberous root yield.

Table 4:- Effect of the interaction between $N$ fertilizer types and concentrations of microelements mixtures on yield and it s components of sweet potato during the summer seasons of 2017 and 2018.

\begin{tabular}{|c|c|c|c|c|c|c|}
\hline Treatments & & $\begin{array}{l}\text { Root length } \\
(\mathrm{cm})\end{array}$ & $\begin{array}{l}\text { Root weight } \\
\text { (gm) }\end{array}$ & $\begin{array}{c}\text { Root diameter } \\
(\mathrm{cm})\end{array}$ & $\begin{array}{c}\text { Average No. of } \\
\text { roots/plant }\end{array}$ & $\begin{array}{l}\text { Total yield } \\
\text { (Ton/fed) }\end{array}$ \\
\hline $\begin{array}{l}N \text { fertilizer } \\
\text { types }\end{array}$ & $\begin{array}{c}\text { Microelements } \\
(\%)\end{array}$ & \multicolumn{5}{|c|}{ Summer Season 2017} \\
\hline \multirow{4}{*}{ Control } & 0 & $18.56 \mathrm{f}$ & $176.73 \mathrm{e}$ & $4.20 \mathrm{ef}$ & $4.86 \mathrm{gh}$ & $12.04 \mathrm{~d}$ \\
\hline & 10 & $19.80 \mathrm{c}$ & $185.16 \mathrm{~cd}$ & $4.66 \mathrm{~cd}$ & $5.06 \mathrm{ef}$ & $13.34 \mathrm{c}$ \\
\hline & 20 & $21.00 \mathrm{~b}$ & $190.66 \mathrm{bc}$ & $5.00 \mathrm{bc}$ & $5.53 \mathrm{bc}$ & $14.77 \mathrm{~b}$ \\
\hline & 30 & $22.03 \mathrm{a}$ & $203.23 \mathrm{a}$ & $5.56 \mathrm{a}$ & $5.93 \mathrm{a}$ & $16.87 \mathrm{a}$ \\
\hline \multirow{4}{*}{$\mathrm{T} 1$} & 0 & $17.86 \mathrm{~h}$ & $145.93 \mathrm{j}$ & $4.13 \mathrm{f}$ & 3.801 & $7.74 \mathrm{~g}$ \\
\hline & 10 & $18.16 \mathrm{gh}$ & $150.33 \mathrm{ij}$ & $4.00 \mathrm{f}$ & $4.00 \mathrm{k}$ & $8.41 \mathrm{~g}$ \\
\hline & 20 & $18.63 \mathrm{ef}$ & $155.66 \mathrm{hi}$ & $4.16 \mathrm{ef}$ & $4.40 \mathrm{j}$ & $9.58 \mathrm{f}$ \\
\hline & 30 & $19.06 \mathrm{~d}$ & $167.50 \mathrm{f}$ & $4.50 \mathrm{de}$ & $4.50 \mathrm{ij}$ & $10.54 \mathrm{e}$ \\
\hline \multirow{4}{*}{ T 2} & 0 & $18.50 \mathrm{fg}$ & $166.50 \mathrm{fg}$ & $4.00 \mathrm{f}$ & $5.00 \mathrm{fg}$ & $10.72 \mathrm{e}$ \\
\hline & 10 & $19.83 \mathrm{c}$ & $185.66 \mathrm{~cd}$ & $4.10 \mathrm{f}$ & $5.23 \mathrm{~d}$ & $13.60 \mathrm{c}$ \\
\hline & 20 & $20.76 \mathrm{~b}$ & $191.33 \mathrm{bc}$ & $4.60 \mathrm{~d}$ & $5.66 \mathrm{~b}$ & $15.17 \mathrm{~b}$ \\
\hline & 30 & $21.80 \mathrm{a}$ & $195.50 \mathrm{~b}$ & $5.33 \mathrm{ab}$ & $6.03 \mathrm{a}$ & $16.49 \mathrm{a}$ \\
\hline \multirow{4}{*}{ T 3} & 0 & $18.00 \mathrm{~h}$ & $160.00 \mathrm{gh}$ & $4.16 \mathrm{ef}$ & $4.60 \mathrm{i}$ & $10.51 \mathrm{e}$ \\
\hline & 10 & $19.00 \mathrm{de}$ & $164.76 \mathrm{fg}$ & $4.66 \mathrm{~cd}$ & $4.83 \mathrm{~h}$ & $11.14 \mathrm{e}$ \\
\hline & 20 & $19.70 \mathrm{c}$ & $179.33 \mathrm{de}$ & $5.03 \mathrm{~b}$ & $5.16 \mathrm{de}$ & $12.97 \mathrm{c}$ \\
\hline & 30 & $20.76 \mathrm{~b}$ & $191.83 \mathrm{bc}$ & $5.40 \mathrm{a}$ & $5.46 \mathrm{c}$ & $14.67 \mathrm{~b}$ \\
\hline & & \multicolumn{5}{|c|}{ Summer Season 2018} \\
\hline \multirow{4}{*}{ Control } & 0 & $17.90 \mathrm{~g}$ & $182.66 \mathrm{fg}$ & $4.10 \mathrm{ij}$ & $4.86 \mathrm{f}$ & $12.44 \mathrm{eg}$ \\
\hline & 10 & $18.26 \mathrm{e}$ & $189.00 \mathrm{~d}-\mathrm{f}$ & $4.46 \mathrm{ef}$ & $5.03 \mathrm{ef}$ & $13.31 \mathrm{~d}-\mathrm{f}$ \\
\hline & 20 & $18.70 \mathrm{c}$ & $199.33 \mathrm{~b}$ & $4.90 \mathrm{c}$ & $5.30 \mathrm{~cd}$ & $14.79 \mathrm{~b}-\mathrm{d}$ \\
\hline & 30 & $19.10 \mathrm{a}$ & $209.33 \mathrm{a}$ & $5.56 \mathrm{a}$ & $5.83 \mathrm{a}$ & $17.09 \mathrm{a}$ \\
\hline \multirow{4}{*}{$\mathrm{T} 1$} & 0 & $16.33 \mathrm{k}$ & $165.33 \mathrm{j}$ & $3.93 \mathrm{k}$ & $3.76 \mathrm{i}$ & $8.71 \mathrm{i}$ \\
\hline & 10 & $16.93 \mathrm{j}$ & $173.00 \mathrm{hi}$ & $4.00 \mathrm{jk}$ & $4.16 \mathrm{~h}$ & $10.09 \mathrm{hi}$ \\
\hline & 20 & $17.46 \mathrm{~h}$ & $180.00 \mathrm{gh}$ & $4.26 \mathrm{gh}$ & $4.26 \mathrm{~h}$ & $10.75 \mathrm{gh}$ \\
\hline & 30 & $17.93 \mathrm{j}$ & $180.66 \mathrm{~g}$ & $4.56 \mathrm{e}$ & $4.60 \mathrm{~g}$ & $11.63 \mathrm{f}-\mathrm{h}$ \\
\hline \multirow{4}{*}{ T 2} & 0 & $17.23 \mathrm{i}$ & $180.00 \mathrm{gh}$ & $4.16 \mathrm{hi}$ & $4.93 \mathrm{f}$ & $12.43 \mathrm{e}-\mathrm{g}$ \\
\hline & 10 & $17.83 \mathrm{~g}$ & $184.33 \mathrm{e}-\mathrm{g}$ & $4.43 \mathrm{f}$ & $5.43 \mathrm{c}$ & $14.01 \mathrm{c}-\mathrm{e}$ \\
\hline & 20 & $18.13 \mathrm{ef}$ & $191.66 \mathrm{c}-\mathrm{e}$ & $4.80 \mathrm{~cd}$ & $5.76 \mathrm{ab}$ & $15.47 \mathrm{a}-\mathrm{c}$ \\
\hline & 30 & $18.86 \mathrm{bc}$ & $199.00 \mathrm{bc}$ & $5.33 \mathrm{~b}$ & $5.93 \mathrm{a}$ & $16.53 \mathrm{ab}$ \\
\hline \multirow{4}{*}{ T 3} & 0 & $17.20 \mathrm{i}$ & $172.33 \mathrm{ij}$ & $4.00 \mathrm{jk}$ & $4.86 \mathrm{f}$ & $11.72 \mathrm{f}-\mathrm{h}$ \\
\hline & 10 & $18.00 \mathrm{fg}$ & $181.33 \mathrm{~g}$ & $4.36 \mathrm{gf}$ & $5.16 \mathrm{de}$ & $13.11 \mathrm{~d}-\mathrm{f}$ \\
\hline & 20 & $18.50 \mathrm{~d}$ & $189.66 \mathrm{~d}-\mathrm{f}$ & $4.73 \mathrm{~d}$ & $5.43 \mathrm{c}$ & $11.90 \mathrm{f}-\mathrm{h}$ \\
\hline & 30 & $18.93 \mathrm{ab}$ & $193.00 \mathrm{~b}-\mathrm{d}$ & $5.33 \mathrm{~b}$ & $5.63 \mathrm{~b}$ & $15.22 \mathrm{a}-\mathrm{c}$ \\
\hline \multirow{2}{*}{\multicolumn{3}{|c|}{$\begin{array}{l}\text { Control: } 60 \mathrm{Kg} \mathrm{N} \backslash \text { fed. } \\
\mathrm{T}_{1::} 15 \mathrm{Kg} \mathrm{N} / \mathrm{fed}+1.5 \mathrm{~m}^{3} \text { compost }\end{array}$}} & \multicolumn{4}{|c|}{$\mathrm{T} 2: 30 \mathrm{Kg} \mathrm{N} / \mathrm{fed}+1 \mathrm{~m}^{3}$ compost } \\
\hline & & & \multicolumn{3}{|c|}{$\mathrm{T} 3 .: 45 \mathrm{Kg} \mathrm{N} / \mathrm{fed}+0.5 \mathrm{~m}^{3}$ compost } & \\
\hline
\end{tabular}




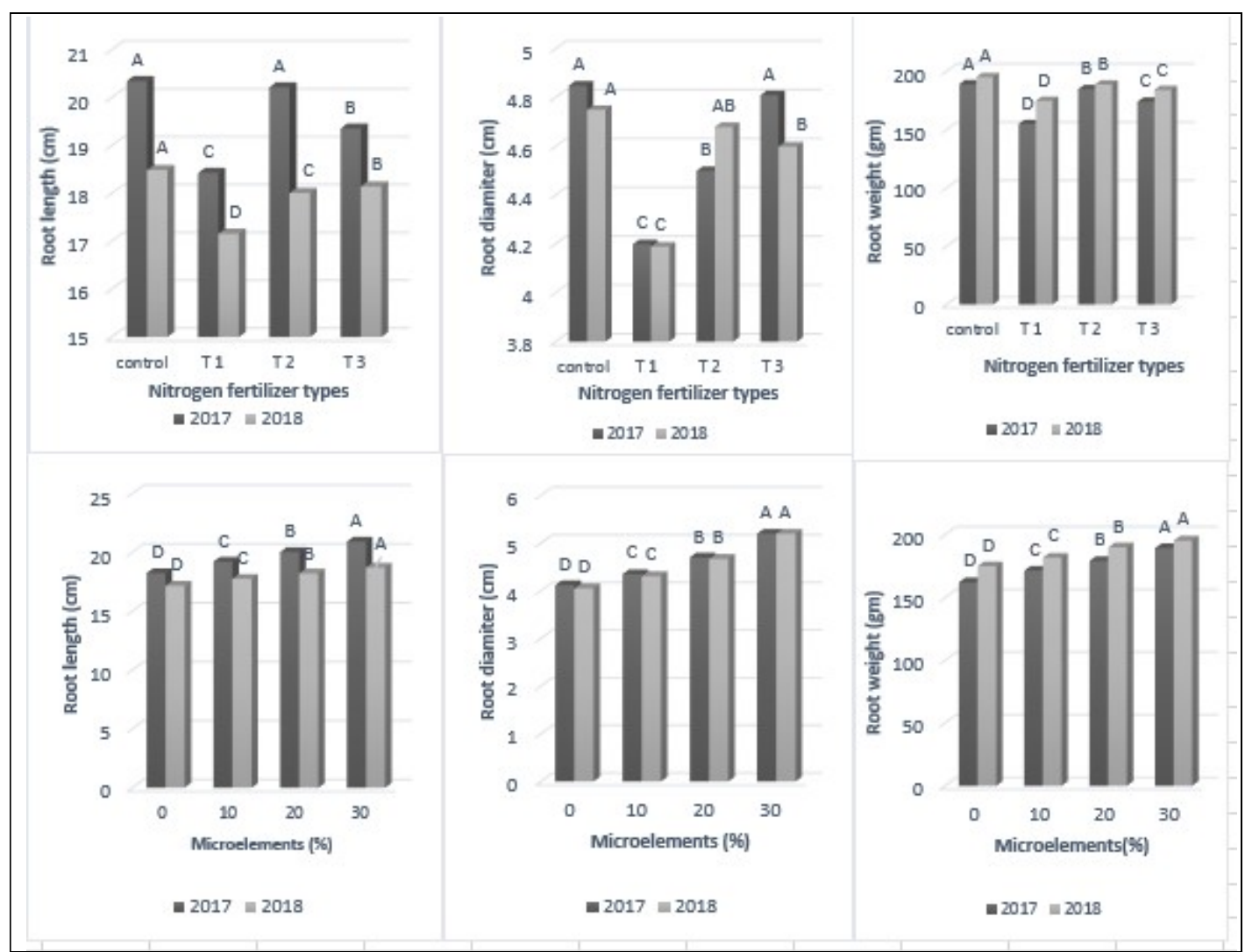

Fig. 2-a: Effect of organic fertilizer and foliar application with microelements on yield and it's components of sweet potato during both seasons of 2017 and 2018.

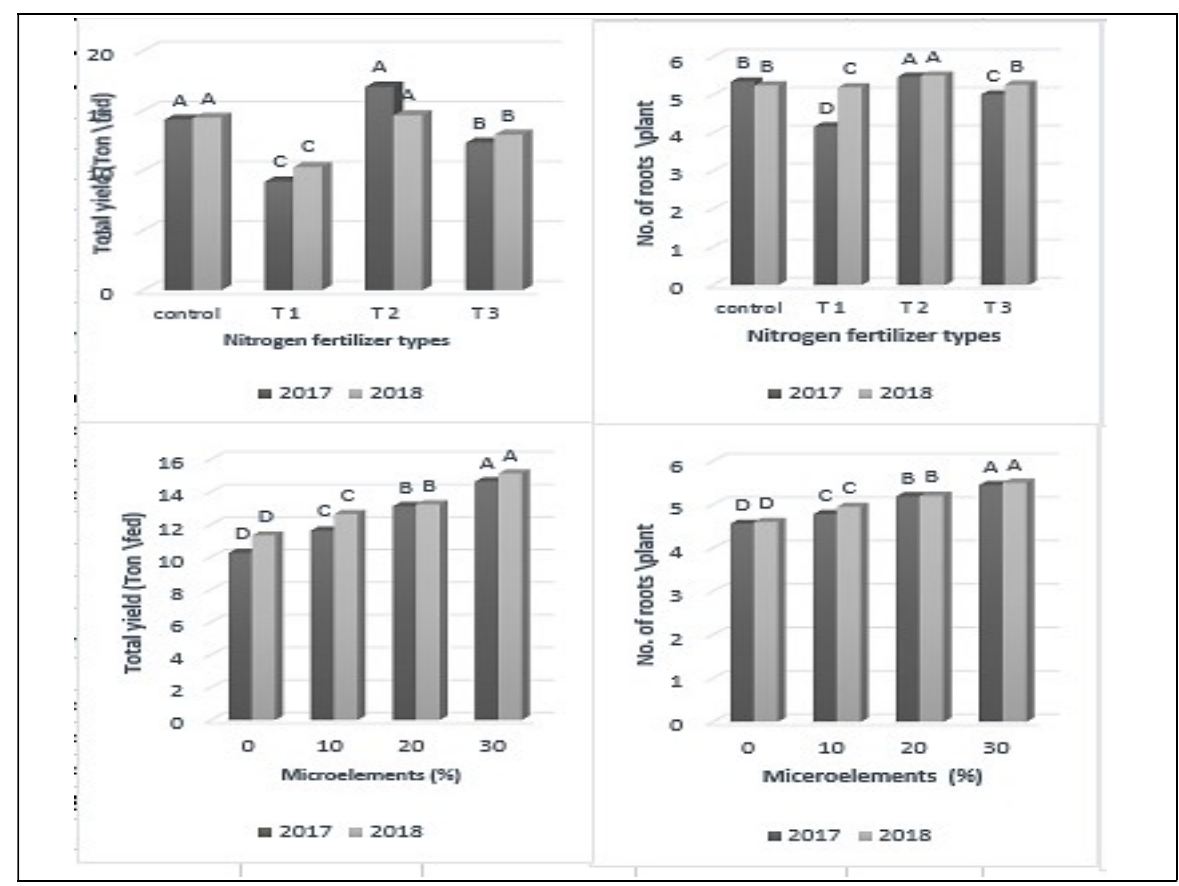

Fig. 2-b: Effect of organic fertilizer and foliar application with microelements on yield and it's components of sweet potato during both seasons of 2017 and 2018. 


\section{Chemical constituents of tuberous roots}

Data arranged in Figure (3) and Table (5) illustrated that the main effects of the two studied factors and their interaction, respectively on some chemicals constituent on the produced tuberous roots of sweet potato in the two growing seasons. Regarding the main effects of $\mathrm{N}$ fertilizer types, the results of the two seasons (Fig.3) indicated, generally, that fertilizing sweet potato plants with 15 $\mathrm{kg} \mathrm{N}+1.5 \mathrm{~m}^{3}$ compost or $30 \mathrm{~kg} \mathrm{~N}+1 \mathrm{~m}^{3}$ compost fed. $^{-1}$ produced tuberous roots with the highest contents of dry matter, carotene, starch and total sugars as compared to other treatments. However the lowest mean values of the analyzed chemical constituents were recorded when plants fertilized with $60 \mathrm{~kg} \mathrm{Nfed} .^{-1}$.

Regarding the main effect of the microelements, in two seasons (Fig. 3) clearly indicated that increasing the concentration of up to

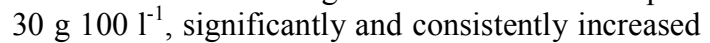
the tuberous roots contents of dry matter, total sugars and starch.

The results could be explained on the bases that microelements had important roles in increasing photosynthesis efficiency and synthesis of carbohydrates such as sugars and starch (Mousavi et al., 2012). Mousavi et al., (2007) indicated that sparying potato plants with $\mathrm{Zn}$ and $\mathrm{Mn}$ increased all characters relating to tuber quality. Moreover, Khairi et al., (2016) found that application of sweet potato plants with $\mathrm{Zn}$ enhanced tuberous roots' of total sugar and carotene contents.

Respecting the effects of the interaction between the two studied factors on the chemical constitute of tuberous roots of sweet potato, in the two growing seasons, are listed in Table (5). The results, generally, revealed that, increasing the concentration of the used microelements mixture up to $30 \mathrm{~g} \mathrm{l}^{-1}$ tented to maximizing the effects of the tested $\mathrm{N}$ fertilizer types on increasing the tuberous roots' content of the analyzed chemical constituents. Such effect was pronounced with the treatments combinations of $15 \mathrm{~kg} \mathrm{~N}+1.5 \mathrm{~m}^{3}$ compost or $30 \mathrm{~kg}$ $\mathrm{N}+1 \mathrm{~m}^{3}$ compost fed ${ }^{-1}$. Coupled with the highest concentration of microelements mixture (30 g $100 \mathrm{l}^{-1}$ ). Whereas, the lowest mean values were recorded with $60 \mathrm{~kg} \mathrm{~N}$ fed. ${ }^{-1}$ and sprayed with 0.0 or $10 \mathrm{~g}$ microelements mixture $100 \mathrm{l}^{-1}$.

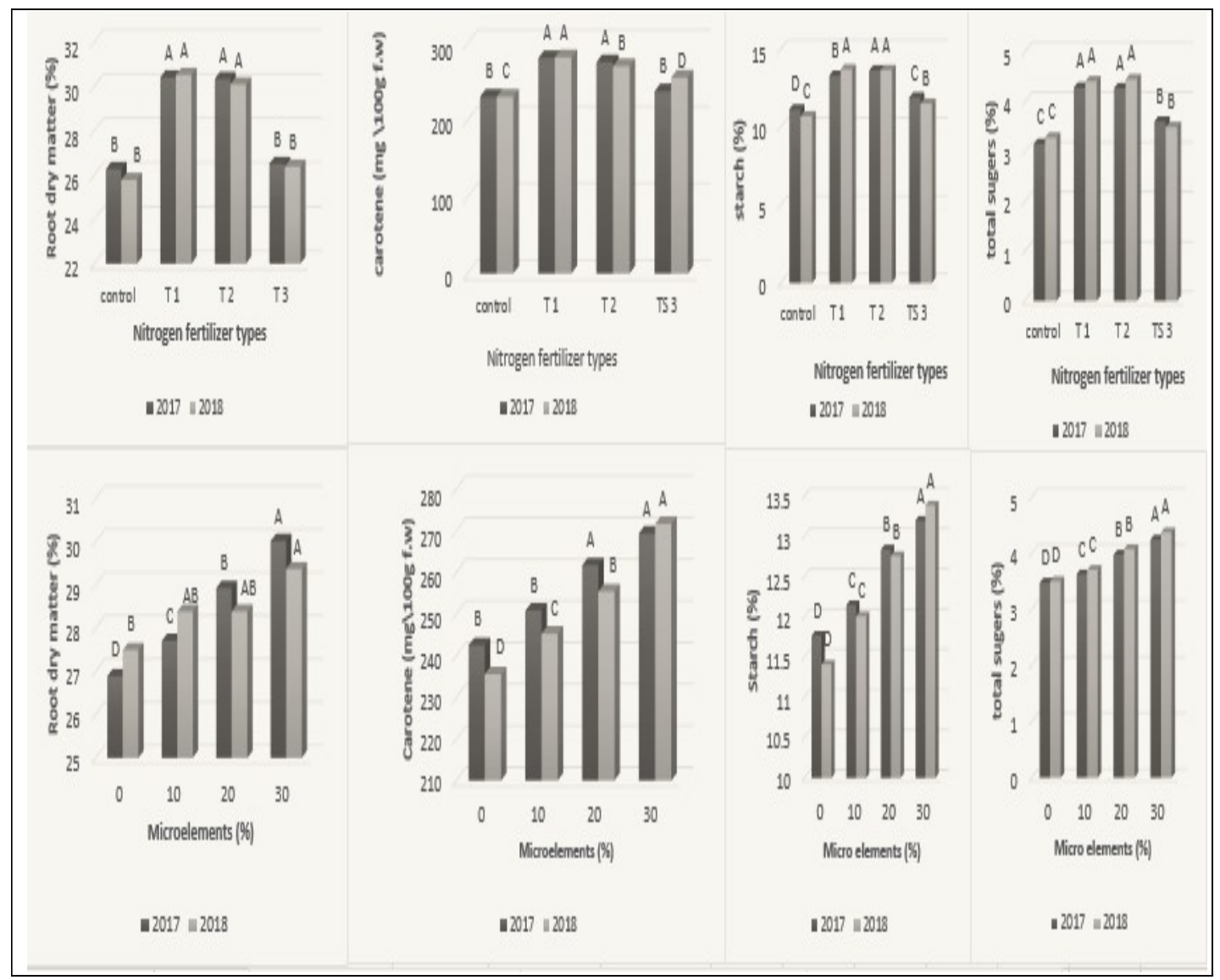

Fig. 3: Effect of organic fertilizer and foliar application with microelements on chemical characteristics of sweet potato plant during both seasons of 2017 and 2018. 
Table 5: Effect of the interaction between $N$ fertilizer types and concentrations of microelements mixtures on chemical characteristics of sweet potato plant.

\begin{tabular}{|c|c|c|c|c|c|}
\hline Treatments & & $\begin{array}{c}\text { Total sugars } \\
(\%) \\
\end{array}$ & $\begin{array}{c}\text { Starch } \\
(\%) \\
\end{array}$ & $\begin{array}{c}\text { Root D.M } \\
(\%) \\
\end{array}$ & $\begin{array}{l}\text { Carotene } \\
(\mathrm{mg} / 100 \mathrm{~g} \text { f.w })\end{array}$ \\
\hline $\begin{array}{l}N \text { fertilizer } \\
\text { types }\end{array}$ & $\begin{array}{c}\text { Micro elements } \\
(\%) \\
\end{array}$ & \multicolumn{4}{|c|}{ Summer Season 2017} \\
\hline \multirow{4}{*}{ Control } & 0 & $3.00 \mathrm{i}$ & $10.43 \mathrm{j}$ & $25.83 \mathrm{gh}$ & $222.80 \mathrm{e}$ \\
\hline & 10 & $3.00 \mathrm{i}$ & $10.83 \mathrm{i}$ & $25.96 \mathrm{gh}$ & $228.40 \mathrm{e}$ \\
\hline & 20 & $3.23 \mathrm{~h}$ & $11.36 \mathrm{~h}$ & $26.4 \mathrm{fg}$ & $231.40 \mathrm{de}$ \\
\hline & 30 & $3.40 \mathrm{~g}$ & $11.93 \mathrm{~g}$ & 26.9 ef & $239.66 \mathrm{de}$ \\
\hline \multirow{4}{*}{$\mathrm{T} 1$} & 0 & $3.83 \mathrm{f}$ & $12.43 \mathrm{f}$ & $28.23 \mathrm{~d}$ & $24983 \mathrm{~d}$ \\
\hline & 10 & $4.00 \mathrm{de}$ & $12.93 \mathrm{e}$ & $29.26 \mathrm{c}$ & $278.40 \mathrm{bc}$ \\
\hline & 20 & $4.50 \mathrm{~b}$ & $13.66 \mathrm{c}$ & $31.36 \mathrm{~b}$ & $293.23 \mathrm{ab}$ \\
\hline & 30 & $4.80 \mathrm{a}$ & $14.16 \mathrm{~b}$ & $32.83 \mathrm{a}$ & $302.03 \mathrm{a}$ \\
\hline \multirow{4}{*}{ Т 2} & 0 & $3.86 \mathrm{f}$ & $12.90 \mathrm{e}$ & $28.00 \mathrm{~d}$ & $248.66 \mathrm{~d}$ \\
\hline & 10 & $4.06 \mathrm{~d}$ & $13.30 \mathrm{~d}$ & $29.46 \mathrm{c}$ & $268.83 \mathrm{c}$ \\
\hline & 20 & $4.33 \mathrm{c}$ & $13.83 \mathrm{bc}$ & $31.10 \mathrm{~b}$ & $288.56 \mathrm{ab}$ \\
\hline & 30 & $4.83 \mathrm{a}$ & $14.53 \mathrm{a}$ & $32.83 \mathrm{a}$ & $295.66 \mathrm{ab}$ \\
\hline \multirow{4}{*}{ T 3} & 0 & $3.20 \mathrm{~h}$ & $11.33 \mathrm{~h}$ & $25.5 \mathrm{~h}$ & $248.73 \mathrm{~d}$ \\
\hline & 10 & $3.43 \mathrm{~g}$ & $11.56 \mathrm{~h}$ & $26.16 \mathrm{f}-\mathrm{h}$ & $227.56 \mathrm{e}$ \\
\hline & 20 & $3.80 \mathrm{f}$ & $12.50 \mathrm{f}$ & $26.86 \mathrm{ef}$ & $233.56 \mathrm{de}$ \\
\hline & 30 & $3.90 \mathrm{ef}$ & $12.20 \mathrm{fg}$ & $27.53 \mathrm{de}$ & $240.10 \mathrm{de}$ \\
\hline & & \multicolumn{4}{|c|}{ Summer Season 2018} \\
\hline \multirow{4}{*}{ Control } & 0 & $3.06 \mathrm{i}$ & $10.00 \mathrm{j}$ & $24.66 \mathrm{~h}$ & $215.36 \mathrm{j}$ \\
\hline & 10 & $3.03 \mathrm{i}$ & $10.36 \mathrm{j}$ & $25.73 \mathrm{gh}$ & $226.86 \mathrm{hi}$ \\
\hline & 20 & $3.46 \mathrm{gh}$ & $11.00 \mathrm{i}$ & $26.16 \mathrm{f}-\mathrm{h}$ & $231.36 \mathrm{gh}$ \\
\hline & 30 & $3.56 \mathrm{fg}$ & $11.46 \mathrm{gh}$ & $26.60 \mathrm{f}-\mathrm{h}$ & $247.73 \mathrm{f}$ \\
\hline \multirow{4}{*}{$\mathrm{T} 1$} & 0 & $4.00 \mathrm{e}$ & $12.06 \mathrm{f}$ & $28.66 \mathrm{~d}-\mathrm{f}$ & $261.43 \mathrm{e}$ \\
\hline & 10 & $4.16 \mathrm{~d}$ & $13.43 \mathrm{~cd}$ & $29.66 \mathrm{~b}-\mathrm{d}$ & $269.70 \mathrm{~d}$ \\
\hline & 20 & $4.56 \mathrm{c}$ & $14.40 \mathrm{~b}$ & $31.50 \mathrm{a}-\mathrm{c}$ & $285.7 \mathrm{c}$ \\
\hline & 30 & $4.93 \mathrm{~b}$ & $14.90 \mathrm{a}$ & $32.3 \quad \mathrm{a}$ & $310.56 \mathrm{a}$ \\
\hline \multirow{4}{*}{ T 2} & 0 & $3.93 \mathrm{e}$ & $12.73 \mathrm{e}$ & $29.13 \mathrm{c}-\mathrm{e}$ & $252.86 \mathrm{f}$ \\
\hline & 10 & $4.20 \mathrm{~d}$ & $13.10 \mathrm{de}$ & $29.4 \mathrm{~cd}$ & $259.56 \mathrm{e}$ \\
\hline & 20 & $4.60 \mathrm{c}$ & $13.80 \mathrm{c}$ & $29.96 \mathrm{a}-\mathrm{d}$ & $275.13 \mathrm{~d}$ \\
\hline & 30 & $5.10 \mathrm{a}$ & $15.03 \mathrm{a}$ & $31.93 \mathrm{ab}$ & $293.26 \mathrm{~b}$ \\
\hline \multirow{4}{*}{ T 3} & 0 & $3.00 \mathrm{i}$ & $10.86 \mathrm{i}$ & $27.56 \mathrm{~d}-\mathrm{g}$ & $212.43 \mathrm{j}$ \\
\hline & 10 & $3.40 \mathrm{~h}$ & $11.16 \mathrm{hi}$ & $25.40 \mathrm{gh}$ & $225.03 \mathrm{i}$ \\
\hline & 20 & $3.66 \mathrm{f}$ & $11.86 \mathrm{fg}$ & $25.93 \mathrm{gh}$ & $229.43 \mathrm{~g}-\mathrm{i}$ \\
\hline & 30 & $3.90 \mathrm{e}$ & $12.16 \mathrm{f}$ & $26.66 \mathrm{e}-\mathrm{h}$ & $235.00 \mathrm{~g}$ \\
\hline \multicolumn{2}{|c|}{ Control: $60 \mathrm{Kg}$ N\fed. } & \multicolumn{3}{|c|}{$\mathrm{T} 2.30 \mathrm{Kg} \mathrm{N} / \mathrm{fed}+1 \mathrm{~m}^{3}$ compost } & \\
\hline \multicolumn{2}{|c|}{$\mathrm{T} 1 .: 15 \mathrm{Kg} \mathrm{N} / \mathrm{fed}+1.5 \mathrm{~m}^{3}$ compost } & \multicolumn{3}{|c|}{$\mathrm{T} 3 .: 45 \mathrm{Kg} \mathrm{N} / \mathrm{fed}+0.5 \mathrm{~m}^{3}$ compost } & \\
\hline
\end{tabular}

\section{REFERENCE}

A.O.A.C. 1990. Association of official agriculture chemists $13^{\text {th }}$ Ed. Washington, D.C.,U.S.A.

Abd El-Aal, H. A; A. N. Abo El-Fadl. and S. A. Moussa. 2010. Effect of mineral and organic potassium fertilization on sweet potato crop grown in the newly reclaimed land. Alex. Scie. Exch. J. 31(3).
Agyarko, K.; H. K. Dapaah; S. Buah and K. A. Frimpong. 2014. Sweet Potato (Ipomoea batatas) Yield Parameters, Soil Chemical Properties and Cost Benefit Ratios Following Incorporation of Poultry Manure and Inorganic NPK Fertilizers in Low Nutrient Ghanaian Soils. Inte. J. Plan. \& Soi. Scie. 3(2): 129-138. 
Ali, R.A.M and D.Y Abd-Elkader. 2014. Influence of application systems of $\mathrm{K}_{2} \mathrm{SO}_{4}$ and foliar application of micronutrient mixtures on cassava grown in sandy soil. Ale. Sci. Exc. J. 35(4): 314 - 324 .

Ashour, S.A. and S.H. Sarhan. 1998. Effect of organic and inorganic fertilizers on growth, yield and tuber quality of potato (Solanum tuberosum L.). J. Agric. Sci. Manesoura Univ. 23(7): 3359-3368.

Babaeian, M; A. Tavassoli; A. Ghanbari; Y. Esmaeilian and M. Fahimifard. 2011. Effects of foliar micronutrient application on osmotic adjustments, grain yield and yield components in sunflower (Alstar cultivar) under water stress at three stages. African Journal of Agricultural Research, 6(5): 12041208.

Bozorgi, H.A.; E. Azarpour and M. Moradi. 2011. The effects of bio, mineral nitrogen fertilization and foliar zinc spraying on yield and yield components of faba bean. World Applied Science Journal, 13(6): 1409-1414.

Co-State Software. 2004. User's manual version. Cohort Tusson, Arizona, USA.Davies, B. H. 1976. Analysis of carotenoid pigment. In: T. W. Goodwin (ed.), Chemistry and Biochemistry of Plant Pigments. Academic Press, London and New York.

El-Tohamy, W.A.; H.M. El-Abagy; S.D. AbouHussein; S.M. Singer and S.O. El-Abd. 2014. Responses of some sweet potato (Ipomoea batatas L.) cultivars to foliar application of micronutrients under sandy soil conditions. Res. J. Agric. \& Biol. Sci., 10(2): 87-92.

Feleafel, M.N.2001. Effect of topping under varying levels of $\mathrm{N}$ and $\mathrm{K}$ fertilizers on growth, yield potential and quality of sweet potato. J.Agric. Sci. Mansoura Univ. 26(2): 87-94.

Hafeez, B; Y.M. Khanif and M. Saleem. 2013. Role of zinc in plant nutrition. Ame. J. Expe. Agri. 3(2): 374-91.

Khairi, M.; N. M. Sarmila; A.M. Naqib and S. M.D. Jahan. 2016. Compost and zinc application enhanced production of sweet potatoes in sandy soil. J. Agri. Res. 1(2): 1-8.

Kinaci, E. and N. Gulmezoglu. 2007. Grain yield and yield components of triticale upon application of different foliar fertilizers. Interciencia, 32(9): 624-628.

Kołodziejczyk, M. 2014. Effect of nitrogen fertilization and microbial preparations on potato yielding. Pla. Soi. Env.. 60(8): 379386.

Malik, C.P. and M.B. Singh. 1980. Plant enzmology and histoenzymology. A Text Manual-Kalyani Publishers, New Delhi.
Meissnor- Smejkal. 2000. Soil microbial activities in organic conventional vegetable gardening a sensitive instrument of horticulture research. Acta. Hort. 513: 145-152.

Mousavi, S.R.; M. Galavi and G. Ahmady. 2007. Effect of zinc and manganese foliar application on yield, quality and enrichment on potato (Solanum tuberosum L.). Asian Journal of Plant Sciences 6(8): 1256-1260.

Mousavi, S.R.; Galavi, M. and Rezaei, M. 2012. The interaction of zinc with other elements in plants: a review. Intl J Agr. Cro. Sci. 4(24): 1881-1884.

Narimani, H.; M.M.Rahimi; Ahmadikhah, A, Vaezi, B., 2010. Study on the effects of foliar spray of micronutrient on yield and yield components of durum wheat. Archive of Applied Science Research, 2(6): 168-176.

Nedunchezhiyan, M.; G. Byju and S.N. Dash. 2010. Effects of organic production of orange fleshed sweet potato (Ipomoea batatas L.) on root yield, quality and soil biological health. Int. Res. J. Pla. Sci. 1(6): 136-143.

Njira, K. and J. Nabwami. 2015. A review of effects of nutrients elements on cop quality. Ajfand. 15(1): 9777- 9793.

Nwite, J.C. 2016. Enhancing soil fertility status, sweet potato yield and tuber nutrient composition through different manure sources in southeastern Nigeria. Archives of Current Research International (ACRI). 4(3): $1-11$.

Page, A.L.1982. Methods of soil analysis, part 2 :chemical and microbiological properties. Amer. Soc. Agron., Madison, Wisconsin, USA.

Panitnok, K; S. Chaisri; E.d. Sarobol; S. Ngamprasitthi; P. Chaisri; P. Changlek and P. Thongluang. 2013. The combination effects of zinc, magnesium, sulphur foliar fertilizer management on cassava growth and yield grown on map bon, coarse-loamy variant Soil. Procedia - Social and Behavioral Sciences 91: 288 - 293.

Panwar, S. and A.M. Wani. 2014. Effect of Organic production on growth and productivity of Sweet Potato (Ipomoea batatas L.) under Poplar based Agroforestry system. Int. J. Adv. Res. 2(12): 229-232.

Raghav, M and S. Kamal. 2009. Effect of organic sources of nutrients on potato production in Tarai region of Uttarakhand. Pantnagar. J. Res. 7(1): 69-72.

Rani, P. 2015. Effect of foliar application of urea and micronutrients on garlic seed production. M.Sc. Thesis Haryana University, Hisar, India. 
Sanginga, N .2015. Root and Tuber Crops (Cassava, Yam, Potato and Sweet Potato). An action plain four African agriculture Transformation 21-23 October.

Snedecor, G. W. and W. G. Cochron.1980. Statistical Method, $7^{\text {th }}$ ed. Iowa State University Press, Ames,pp.507.
Sowley E.N.K.; M. Neindow and A.H Abubakari.

2015. Effect of poultry manure and NPK on yield and storability of orange-and whitefleshed sweet potato [Ipomoea batatas (L.) Lam]. J. Fod. \& Agr. Sci. 5(1):1-6.

Zaman, A.; A. Sarkar; S. Sarkar and W.P. Devi. 2011. Effect of organic and inorganic sources of nutrients on productivity, specific gravity and processing quality of potato (Solanum tuberosum L.). Ind. J Agri. Sci. 81(12): 1137-1142.

\title{
الملخص العربي
}

\section{تأثير استخدام انواع مختلفة من الأسمدة النيتروجينية والرش بالعناصر الصغرى على النمو والمحصول والمحتوى الكيمياوى لجذور ونباتات البطاطا}

\author{
رمضان عبد العاطى محمد على البطى \\ مركز البحوث الزراعية- معهد بحوث البساتين- قسم بحوث البطاطس و الخضر خضرية التكاثر
}

تم دراسة تأثير أنو اع مختلفة من السماد النتزوجينى و الرش بالعناصر الصغرى على النمو الخضرى و المحصول

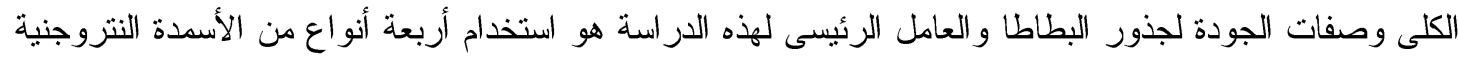
المختلفة وهى (.ب كجم وحدة نتروجين من السماد المعنى وهو المعدل الموصى به و إ كجم وحدة نتزوجين

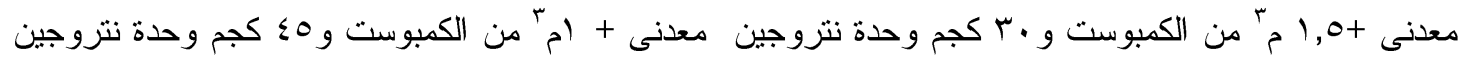

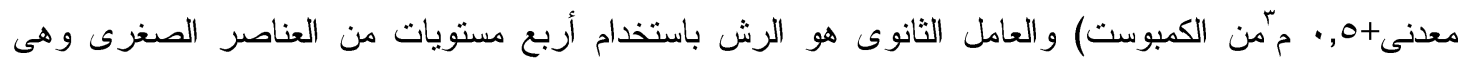

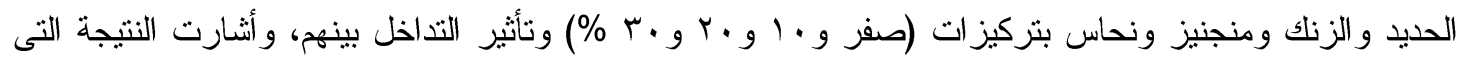

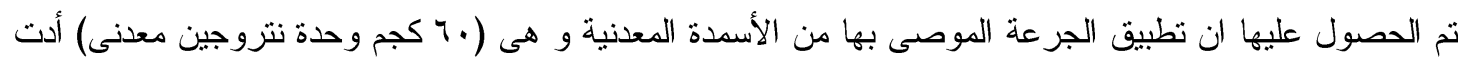

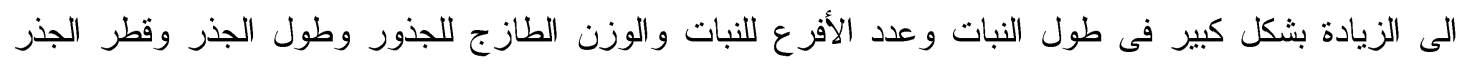

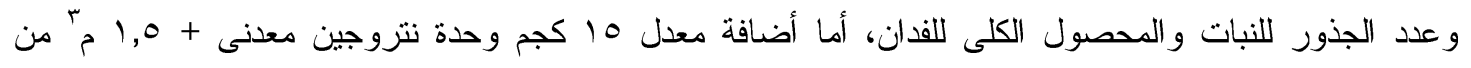

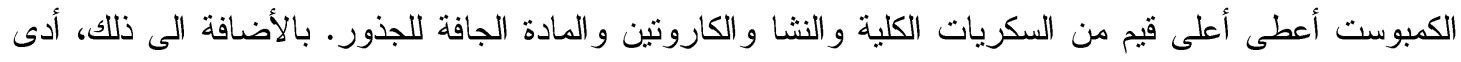

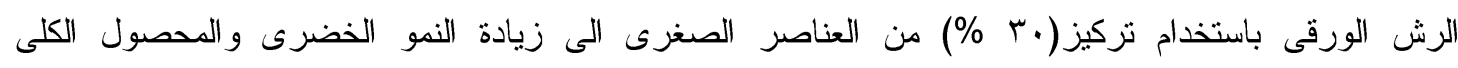
و المحتوى الكيماوى لجذور البطاطا. 